\title{
Efektivitas Pemberian Jus Buah Naga Merah (Hylosereus Polyirhizzus) terhadap Penderita Hipertensi pada Menopause di Posyandu Banjaran Wilayah Kerja Puskesmas Wilayah Utara Kota Kediri
}

\author{
RizaTsalatsatul Mufida ${ }^{1}$ \\ ${ }^{1}$ Dosen Institut Ilmu Kesehatan Surya Mitra Husada \\ Corresponding author: RizaTsalatsatul Mufida (reyzagirlz@gmail.com)
}

Received 27 August 2019; Accepted 28 August 2019; Published 5 September 2019

\begin{abstract}
ABSTRAK
Hipertensi menjadi masalah kesehatan masyarakat yang serius. Hipertensi mengakibatkan bebagai komplikasi pada pembuluh darah.Penatalaksanaan non farmakologis menggunakan jus buah naga merah. Penelitian ini bertujuan untuk mengetahui efektivitas pemberian jus buah naga merah pada penderita hipertensi. Dalam penelitian ini menggunakan Quasy Experimental Design dengan pendekatan one grouppre-test and pos-test design populasi sebanyak 30 orang dan sampel 19 orang. Tehnik sampling menggunakan purposive sampling. Hasil penelitian menunjukan setelah diberikan jus buah naga merah 19 responden yang menderita hipertensi 15 responnden mengalami penurunan tekanan darah dan 4 responden tidak mengalami penurunan tekanan darah (tetap). Berdasarkan hasil uji paired t-test jus buah naga merah. diperoleh nilai p-value sebesar 0,002 atau $p$-value $<\alpha(0,000<0,005)$, artinya $\mathrm{H}_{\mathrm{o}}$ ditolak dan $\mathrm{H}_{\mathrm{I}}$ diterima yang berarti pemberian jus buah naga merah (hylocereus polyrhizzus) efektiv menurunkan hipertensi pada menopause di Posyandu Banjaran Wilayah Kerja Puskesmas Wilayah Utara Kota Kediri. Jus buah naga merah mengandung fitokomia, flavonoid dan kalsium yang efektif dalam menurunkan tekanan darah.
\end{abstract}

Kata Kunci: Hipertensi, Menopause, Buah Naga Merah

Copyright @ 2019 Institut Ilmu Kesehatan STRADA Indonesia All rights reserved.

This is an open-acces article distributed under the terms of the Creative Commons Attribution-ShareAlike 4.0 International License.

\section{PENDAHULUAN}

Hipertensi atau tekanan darah tinggi adalah suatu peningkatan abnormal tekanan darah dalam pembuluh darah arteri secara terus menerus lebih dari suatu periode. Hal ini terjadi bila arteriole konstriksi. Konstriksi arteriole membuat darah sulit mengalir dan meningkatkan tekanan melawan dinding arteri. Hipertensi menambah beban kerja jantung dan arteri yang bila berlanjut dapat menimbulkan kerusakan jantung dan pembuluh darah.

Menurut the sixth Report of the join National committee on prevention, detection, Evaluation and Treatment of High blood pressure berpendapat seseorang tekanan hipertensi jika tekanan darah systole lebih dari $140 \mathrm{mmHg}$ atau tekanan darah diastolic lebih dari $90 \mathrm{mmHg}$ (Hariyanto, dan Sulistyowati, 2015). 
Berdasarkan data Dinas Kesehatan Kota Kediri dari bulan Januari sampai bulan Agustus Tahu 2017 dengan jumlah kunjungan penderita hipertensi pada usia lanjut sebanyak 18.206 orang dimana yang penderita hipertensi pada usia lanjut terbanyak adalah perempuan yaitu 12.263 orang, sedangkan laki-laki sebanyak 5.943 orang (Dinkes Kota Kadiri 2017).

Berdasarkan survey awal yang diperoleh penelitian di Puskesmas Wilayah Utara Kota kediri pada tahun 2017 diperoleh ibu menopause dengan hipertensi sejumlah 1.142 orang. Dan data yang diperoleh di Posyandu Banjaran Wilayah Kerja Puskesmas Wilayah Utara Kota Kediri pada bulan Februari Tahun 2018 didapatkan ibu menopause yang mengalami hipertensi sebanyak 30 orang.

Penatalaksaan pada penderita hipertensi terdiri dari modifikasi pola hidup dan dilanjutkan dengan pemberian obat-obat antihipertensi. Ada beberpa cara untuk menangani hipertensi yaitu terapi farmakologi dan non farmakologis. Dengan terapi farmakologis berarti kita menggunakan obatobatan, sedangkan dengan terapi non farmakologis berarti kita menggunakan bahan-bahan non obat. Salah satuya buah buahan yang membantu menurunkan tekanan darah dan tidak menimbulkan efek samping yaitu buah naga. Dari semua jenis buah naga memiliki beberapa jenis antara lain buah naga putih, buah naga merah, buah naga merah super. Buah naga memiliki kandungan kalium yang ada didalam buah naga yang berfungsi untuk melebarkan pembuluh darah, hingga aliran darah lebih cepat dan lancar dan meringankan kerja jantung memompa darah pada pada penderita hipertensi sehingga menormalkan kembali tekanan darah (Ratih Damayanti, 2013).

Buah Naga mengandung fitokimia dimana dapat menghambat sekresi renin, sehingga kadar Angiotensin II berkurang dan menghasilkan efek antihipertensi yang berdampak langsung pada jantung (Pandji Susilo, 2013). Selain itu buah naga memiliki kandungan senyawa flavonoid yang bekerja sebagai Angiotensin Converting Enzym (ACE) yang berfungsi menurunkan tekanan darah tinggi dan senyawa Flavonoid yang ada pada buah naga daging merah lebih tinggi ( Wu Li Chen et al, 2012).

\section{BAHAN DAN METODE}

Sebelum perlakuan, dilakukan pengukuran tekanan darah pada setiap responden dan dicatat didalam lembar observasi, jus buah naga merah diberikan kepada responden selama 3 hari sebanyak $400 \mathrm{ml} /$ harinya setelah itu di lakukan pengukuran tekanan darah kembali untuk menilai penurunan tekanan darah dan di catat di lembar observasi desaign penelitian yang digunakan penelitian ini merupakan penelitian eksperimen semu (Quasi Experimen) dengan rancangan penelitian The One Group Pratest Posttest yaitu rancangan eksperimen yang dilakukan pada satu kelompok saja tanpa kelompok pembanding. 


\section{HASIL}

Karakteristik Responden

Tabel 1 Karakteristik Responden Berdasarkan Usia, Pendidikan, Pekerjaan, Riwayat Hipertensi dan Konsumsi Obat

\begin{tabular}{lcc}
\hline KARAKTERISTIK & N & $\%$ \\
\hline USIA & & \\
45-55 & 19 & 100 \\
PENDIDIKAN & 8 & 42,1 \\
SD & 5 & 26,3 \\
SMP & 2 & 10,5 \\
SMA & 4 & 21,1 \\
Perguruan Tinggi & & 68,4 \\
PEKERJAAN & 13 & 3,8 \\
IRT & 2 & 21,1 \\
wiraswasta & 4 & 78,9 \\
PNS & & 21,1 \\
RIWAYAT & 15 & 100 \\
HIPERTENSI & 4 & \\
Ada & & \\
Tidak Ada & 19 & \\
KONSUMSI OBAT & & \\
Pernah & & \\
\hline
\end{tabular}

Sumber : Hasil Analisa Data

\section{Karakteristik Variabel}

Tabel 2 Karakteristik Variabel Sebelum dan Sesudah Pemberian Jus Buah Naga

\begin{tabular}{lcc}
\hline Karakteristik & N & \% \\
\hline $\begin{array}{l}\text { Sebelum } \\
\text { Hipertensi Ringan (140- }\end{array}$ & 3 & 15,8 \\
$\begin{array}{l}159 \text { mmHg) } \\
\text { Hipertensi Sedang (160- }\end{array}$ & 8 & 42,1 \\
$\begin{array}{l}179 \text { mmHg) } \\
\text { Hipertensi Berat (>180 }\end{array}$ & 8 & 42,1 \\
$\begin{array}{l}\text { Sesudah } \\
\text { Hipertensi Ringan (140- }\end{array}$ & 16 & 84,2 \\
$\begin{array}{l}159 \text { mmHg) } \\
\text { Hipertensi Sedang (160- } \\
179 \text { mmHg) }\end{array}$ & 3 & 15,8 \\
\hline
\end{tabular}

Sumber: Hasil Analisa Data 


\section{Hasil Uji Statistik}

Uji statistik untuk mengetahui efektivitas pemberian jus buah naga merah terhadap penderita hipertensi (hylocereus polyrhizzus)terhadap penderita hiupertensi pada menopause dengan menggunakan uji paired T-test.

Paired Samples Test

\begin{tabular}{|c|c|c|c|c|c|c|c|c|}
\hline & & \multicolumn{5}{|c|}{ Paired Differences } & \multirow[b]{3}{*}{$\mathrm{t}$} & \multirow[b]{3}{*}{ df Sig. (2-tailed) } \\
\hline & & \multirow[b]{2}{*}{ Mean } & \multirow{2}{*}{$\begin{array}{c}\text { Std. } \\
\text { Deviation }\end{array}$} & \multirow{2}{*}{$\begin{array}{c}\text { Std. Error } \\
\text { Mean }\end{array}$} & \multicolumn{2}{|c|}{$\begin{array}{l}\text { 95\% Confidence } \\
\text { Interval of the } \\
\text { Difference }\end{array}$} & & \\
\hline & & & & & Lower & Upper & & \\
\hline Pair 1 & $\begin{array}{l}\text { TD.sebelum - } \\
\text { TD.sesudah }\end{array}$ & ,421 & ,507 & , 116 & , 177 & & 3,618 &, 002 \\
\hline
\end{tabular}

Berdasarkan tabel 4.11 didapatkan bahwa nilai $p$-value sebesar 0,002 atau $p$-value $<\alpha$ $(0,000<0,005)$, artinya $\mathrm{H}_{0}$ ditolak dan $\mathrm{H}_{1}$ diterima yang berarti pemberian jus buah naga merah (hylocereus polyrhizzus) efektiv menurunkan hipertensi pada menopause di Posyandu Banjaran Wilayah Kerja Puskesmas Wilayah Utara Kota Kediri.

Berdasarkan tabel 4.11 didapatkan bahwa nilai $p$-value sebesar 0,002 atau $p$-value $<\alpha$ $(0,000<0,005)$, artinya $\mathrm{H}_{0}$ ditolak dan $\mathrm{H}_{1}$ diterima yang berarti pemberian jus buah naga merah (hylocereus polyrhizzus) efektiv menurunkan hipertensi pada menopause di Posyandu Banjaran Wilayah Kerja Puskesmas Wilayah Utara Kota Kediri.

\section{PEMBAHASAN}

\section{A. Tekanan Darah Sebelum Diberikan Jus Buah Naga Merah (Hylocereus Polyrhizzus) Terhadap Penderita Hipertensi Pada Menopause Di Posyandu Banjaran Wilayah Kerja Puskesmas Wilayah Utara Kota Kediri.}

Hasil penelitian berdasarkan tabel 4.6 didapatkan bahwa dari 19 total responden terdapat bahwa sebagian kecil dari responden memiliki tekanan darah ringan yaitu sebanyak 3 orang $(15,8 \%)$, dengan kategori hipertensi sedang yaitu hampir sebagian responden sebanyak 8 orang $(42,1 \%)$ dan hampir sebagian responden dengan kategori hipertensi berat yaitu sebanyak 8 orang $(42,1 \%)$ sebelum diberikan jus buah naga merah (hylosereus polyrhizzus).

Tekanan darah pada orang dewasa cenderung meningkat seiring bertambahnya usia dan bisa dihubungkan dengan penurunan elastisitas pembulih darah (Potter \& perry, 2015). Tekana darah sistolik meningkat karenan kelenturan pembuluh darah bessr yang berkurang, pada bertambahnya usia sampai dekade ke tujuh sedangkan sedangkat tekanan diastolik meningkat sampai dekade kelima dan ke enam kemudian menetap atau cenderung menurun. Peningkatn usia akan menyebabkan beberapa perubahan fisiologis, pada usia lanjut terjadi peningkatan resistensi perifer dan aktivitas simpatik (Sutanto, 2013). Setelah menopause wanita cenderung memiliki tekana darah tinggi pada usia tersebut (Ekowati, 2013).

Berdasarkan hasil tabulasi silang antara karakteristik responden dengan variabel pada bab sebelumnya dapat dilihat dari 19 total responden terdapat sebagian besar responden dengan usia 45-55 tahun mengalami hipertensi sedang yaitu sebanyak 8 orang $(42,1 \%)$ sebelum diberikan jus buah naga merah (hylosereus polyrhizzus) dibandingkan dengan hipertensi pada usia 35-45 tahun yaitu sebnyak 3 orang $(15,8 \%)$.

Hasil penelitian sesuai dengan penelitian yang dilakukan oleh Ekowati, bahwa usia ibu berpengaruh terhadap perubahan tekanan darah, dimana ibu yang usianya lebih muda lebih sedikit menderita hipertensi dibandingkan dengan ibu yang sudah tua. Peneliti berasumsi ibu menopause yang mengalami peningkatan darah tinggi dikarenakan bertambahnya usia, dengan semakin meningkatnya usia, kemungkinan seseorang menderita hipertensi juga semakin besar. Penyakit 
hipertensi merupakan penyakit yang timbul akibar adanya interaksi dari berbagai faktor resiko yang dimiliki seseorang. Bebrapa peneliti telah menemukan hubungan antara berbagai faktor resiko terhadap timbulnya hipertensi. Berdasarkan penelitian yang telah dilakukan, ternyata prevalensi, (angka kejadian) meneingkat dengan bertambahanya usia (Sutanto 20014).

Pendidikan adalah proses belajar yang berarti didalam pendidikan terjadi proses pertumbuhan dan perkembangan atau perubahan kearah yang lebih dewasa. Tingkat pendidikan ibu yang rendah mengakibatkan kurangnya pengetahuan ibu dalam menghadapi masalah, terutama dalam peningkatan tekanan darah. Pengetahuan diperoleh baik secara formal maupun informal. Sedangkan ibu yang mempunyai tingkat pendidikan yang lebih tinggi umumnya terbuka menerima perubahan atau hal-hal guna pemeliharaan kesehatannya (Sulistyawati, 2013).

Hasil penelitian sejalan dengan penelitian yang dilakukan sulistyawati, dapat dilihat dari hasil tabulasi silang pendidikan dengan penderita hipertensi terpada tabel 4.3 bahwa dari 19 total responden didapatkan bahwa hampir sebagian responden dengan pendidikan SD yang mengalami hipertensi yaitu sebnyak 8 orang $(42,1 \%)$ sebelum diberikan jus buah naga merah (Hylocereus Polyrhizzus).

Berdasarkan hasil tabulasi silang penderita hipertensi Berdasarkan hasil penelitian dan teori diatas maka peneliti menyimpulkan bahwa mayoritas ibu menopause yang mengalami peningkatan tekanan darah adalah ibu yang berpendidikan rendah. Hal ini disebabkan karena ibu yang berpendidikan rendah akan sulit mencerna, menerima pesan dan informasi yang disampaikan mengenai pentingnya pengetahuan tentang tekanan darah. Sebaiknya ibu menopause yang menderita hipertensi diberikan informasi serta konseling mengenai perubahan pada tekanan darah sejak dini.

Hasil penelitian ini sejalan dengan penelitian yang dilakukan Santoso, dapat dilihat dari hasil tabulasi silang pekerjaan dengan terjadinya peningkatan tekanan darah tinggi pada ibu menopause berdasarkan tabel 4.4 Dari 19 total responden terdapat hampir sebagian responden dengan pekerjaan IRT yang menderita hipertensi sebelum diberikan jus buah naga merah (Hylocereus Polyrhizzus) sebanyak 8 responden $(42,1 \%)$.

Berdasarkan hasil penelitian dan teori diatas maka peneliti menyimpulkan bahwa mayoritas ibu menopause yang menderita hipertensi adalah ibu yang tidak bekerja atau Ibu rumah tangga. Hal ini diakibatkan karena adanya kesibukan keluarga yang menurunkan tingkat perhatian dalam kesehatan sehingga menyebabkan peningkatan tekanan darah karena tidak lancarnya peredaran darah sehingga terjadinya penyumbatan pada pembuluh darah.

Riwayat hipertensi merupakan suatu keadaan tubuh dari tekanan darah yang meningkat akibat dari adanya peningkatan tekanan darah secara kronis (dalam jangka waktu yang cukup lama). Hipertensi juga dapat diartikan sebagai suatu keadaan tekanan darah dimana sistoliknya diatas 140 $\mathrm{mmHg}$ dan diastoliknya diatas $90 \mathrm{mmHg}$.tekanan darah yang yang selalu meningkat atau tinggi menjadi salah satu dari timbulnya faktor resiko pada suatu penyakit seperti stroke, serangan jantung, gagal ginjal (Ignatavicius, 2012).

Hasil penelitian ini sejalan dengan penelitian yang dilakukan ignatavicius, dapat dilihat dari hasil tabulasi silang riwayat hipertensi dengan terjadinya hipertensi pada ibu menopause terdapat pada tabel 4.7 dari 19 total responden didapatkan bahwa hampir sebagian dari responden dengan riwayat hipertensi sebelum diberikan jus buah naga merah (Hylocereus Polyrhizzus) yaitu sebanyak 15 orang $(79 \%)$.

Berdasarkan hasil penelitian dan teori diatas maka peneliti menyimpulkan bahwa mayoritas ibu menopause yang mengalami hipertensi yaitu ibu menopause yang memiliki riwayat hipertensi. Hal ini diakibatkan karena riwayat hipertensi yang terdahulu dan masalah yang sering timbul dan kurangnya pemahaman dalam menangani masalah yang terjadi pada ibu menopause. Peneliti berasumsi bahwa pada ibu menopause yang memiliki riwayat hipertensi lebih beresiko terjadi hipertensi apabila sebelumnya kurang mendapat informasi mengenai pola hidup sehat dan penangan hipertensi secara dini.

Pengobatan hipertensi Pudiastuti, R.D (2011) terapi farmakologis yaitu obat antihipertensi yang dianjurkan oleh JNC VII yaitu diuretika, terutama jenis thiazide (Thiaz) atau aldosteron antagonis, beta blocker, calcium chanel blocker atau calcium antagonist, Angiotensin Converting Enzyme Inhibitor (ACE I), Angiotensin II Receptor Blocker atau AT1 receptor antagonist/ blocker (ARB).

Hasil penelitian ini sejalan dengan penelitian yang dilakukan Pudiastuti, dapat dilihat dari hasil tabulasi silang pengobatan sebelumnya dengan tekanan darah sebelum diberikan jus buah naga 
merah (hylosereus polyrhizzus) terdapat pada tabel 4.9 dari 19 total responden didapatkan bahwa seluruh responden mengkonsumsi obat anti hiopertensi yaitu sebanyak 19 orang (100\%).

Berdasarkan hasil penelitian dan teori diatas maka peneliti menyimpulkan bahwa mayoritas ibu menopause mengkonsumsi obat anti hipertensi. Hal ini terjadi akibat kurangnya pengetahuam tentang tekanan darah yang menyebabkan penyumbatan pada pembuluh darah Flavonoid bekerja sebagai Angiotensin Converting Enzym(ACE) senyawa flavonoid telah terbukti mempunyain efek biologis yang sangat kuat. Sebagai anti oksidan, flavonoid dapat menghambat penggungpalan kepingkeping sel darah, merangsang produksi nitrit oksida yang dapat melebarkan (relaksasi) pembuluh darah, dan juga menghambat sel kangker.

\section{B. Tekanan Darah Sesudah Diberikan Jus Buah Naga Merah (Hylocereus Polyrhizzus) Terhadap Penderita Hipertensi Pada Menopause Di Posyandu Banjaran Wilayah Kerja Puskesmas Wilayah Utara Kota Kediri.}

Hasil penelitian berdasarkan tabel 4.7 dari 19 total responden didapatkan bahwa hampir seluruh responden dengan kategori hipertensi ringan yaitu sebanyak 16 orang (84,2\%) 15 sesudah diberikan jus buah naga merah (hylosereus polyrhizzus).

Menurut Furhman dalam Lianiwati, Flavonoid berfungsi layaknya kalium yaitu mengabsorbsi cairan ion-ion elektrolit seperti natrium yang ada didalam itraseluler darah yang menuju ekstrasseluler memasuki tubulus ginjal. Secara invitro, senyawa flavonoid telah terbukti mempunyain efek biologis yang sangat kuat. Sebagai anti oksidan, flavonoid dapat menghambat penggungpalan keping-keping sel darah, merangsang produksi nitrit oksida yang dapat melebarkan (relaksasi) pembuluh darah, dan juga menghambat sel kangker.

Menurut pendapat peneliti bahwa salah satu kandungan yang terdapat pada buah naga merah yaitu flovonoid yang dapat melenturkan atau memperlebar pembuluh darah sehingga dapat melancarkan peredaran darah dan menurunkan tekanan darah tinggi pada ibu menopause. Hal ini karena kandungan buah naga yang mempunyai manfaat sangat beragam untuk menopause, selain karena kandungan nutrisi dan vitamin yang terkandung dalamnya, kesegaran buah naga mampu menurunkan hipertensi pada menopause, bahkan ada banyak penelitian menyatakan bahwa buah naga sama sekali tidak berbahaya untuk menopause, demikian bisa dijadikan sumber informasi untuk menopause yang menderita tekanan darah tinggi sehingga dapat menurunkan angka kejadian hipertensi pada menopause.

Tidak hanya memiliki rasa yang manis dan segar, buah naga memiliki kandungan gizi yang sangat beragam dan baik untuk menurunkan tekanan darah tinggi. Beberapa kandungan dalam buah naga diantaranya vitamin $\mathrm{B}$, vitamin $\mathrm{C}$, karbohidrat, serat, kalori, lemak tak jenuh, kalsium, protein, fosfor serta memiliki kadar air yang tinggi. Beberapa kandungan gizi dalam buah naga merah Untuk memperlebar pembuluh darah kapiler sehingga meningkatkan aliran darah untuk keluar masuk dari daerah tersebut dan dipercaya mampu membantu menurunkan tekanan darah tinggi pada menopause. Menurut peneliti Mengkonsumsi jus buah naga setiap hari sebanyak $400 \mathrm{ml} / \mathrm{hari}$ pagi dan sore sebelum makan diberikan selama 3 hari diberikan secara teratur dapat berpengaruh terhadap penurunan tekanan darah, setelah tekanan darah turun ibu menopause dapat mengkonsumsi jus buah naga apabila sewaktu-waktu terjadi peningkatan tekanan darah tinggi sebanyak $2 \mathrm{x} / \mathrm{hari}$ atau sebanyak $400 \mathrm{ml} /$ hari. Jus buah naga merah sangat diajnurkan karena tidak terdapat efek samping setelah mengkonsumsi jus buah merah tersebut. Tidak terdapat kontra indikasi : penderita diabetes militus, hipertensi, kolestrol, kanker, stoke, penyakit kardiovaskular dan pada pasien insufisiensi ginjal. Jadi sangat amat dianjurkan untuk di konsumsi oleh semua kalangan terlebih untuk ibu menopause yang menderita hipertensi.

\section{Efektivitas Pemberian Jus Buah Naga Merah (Hylocereus Polyrhizzus) Terhadap Penderita Hipertensi Pada Menopause Di Posyandu Banjaran Wilayah Kerja Puskesmas Wilayah Utara Kota Kediri.}

Berdasarkan tabel 4.11 diperoleh nilai $p$-value sebesar 0,002 atau $p$-value $<\alpha(0,000<0,005)$, artinya $\mathrm{H}_{0}$ ditolak dan $\mathrm{HI}$ diterima yang berarti pemberian jus buah naga merah (hylocereus 
polyrhizzus) efektiv menurunkan hipertensi pada menopause di Posyandu Banjaran Wilayah Kerja Puskesmas Wilayah Utara Kota Kediri.

Flavonoid bekerja sebagai Angiotensin Converting Enzym(ACE) inhibitor dengan menghambat pembentukan angiotensin II dari angiotensin I dengan berkurangnya jumlah angiotensin II, efek vasokontriksi dan sekresi aldosteron semakin berkurang untuk reabsorbsi natrium dan air. Akhirnya tekanan darah akan menurun (Robinson dalam Grafika, 20013).

Flavonoid berfungsi layaknya kalium yaitu mengabsorbsi cairan ion-ion elektrolit seperti natrium yang ada didalam itraseluler darah yang menuju ekstrasseluler memasuki tubulus ginjal (Iraz, et al dalam Septian, et al, 2014). Secara invitro, senyawa flavonoid telah terbukti mempunyain efek biologis yang sangat kuat. Sebagai anti oksidan, flavonoid dapat menghambat penggungpalan kepingkeping sel darah, merangsang produksi nitrit oksida yang dapat melebarkan (relaksasi) pembuluh darah, dan juga menghambat sel kangker (Furhman dalam Lianiwati, 2013).

Menurut pendapat peneliti bahwa jus buah naga mearah (Hylosereus Polyrhizzus) memiliki efektivitas dalam menurunkan tekana darah tinggi pada ibu menopause karena kandungan flavonoid yang dapat melenturkan pembuluh darah sehinng memperlancaran aliran darah dalam tubuh. Untuk mempertahankan tekanan darah ibu menopause yang nornal setelah mengkonsusmsi jus buah naga merah (hylosereus polyrhizzus) $400 \mathrm{ml} /$ hari selama 3 hari secara teratus ibu menopause di anjurkan minum jus buah naga merah (hylosereus polyrhizzus) stiap hari sebanyak 400ml/harinya. Setelah tekanan darah turun ibu menopause dapat mengkonsumsi jus buah naga apabila sewaktu-waktu terjadi peningkatan tekanan darah tinggi sebanyak 2x/hari atau sebanyak $400 \mathrm{ml} / \mathrm{hari}$ Hal ini sejalan dengan teori Bahiyatun karena kandungan yang terdapat dalam jus buah naga merah sehingga terjadi proses pelebaran atau kelenturan kapiler untuk mengurangi tekanan darah pada ibu menopause.

Setelah pemberian jus buah naga merah sebayak $400 \mathrm{ml} /$ hari selama 3 hari. Dari hasil peneliyian membuktikan bahwapemberian jus buah naga merah perbengaruh pada penderita hipertensi, dari 19 responden yang diberikan jus buah naga merah 15 responden mengalami penurunan tekanan darah dan 4 responden tidak mengalami penurunan tekanan darah (tetap).sebelumnya responden banyak yang mengeluh dengan tekanan darahnya yang selalu tinggi, ada juga yang merasakan sakit kepala yang hebat akibat dari hipertensi tersebut. Sesudah pemberian jus buah naga merah responden merasa lebih baik dari sebelumnya. Karena kandungan kalium yang terdapat pada jus buah naga merah dapat melenturkan pembuluh darah, sehingga aliran darah lebih lancar dan juga meringankan kerja jantung sehingga menormalkan kembali tekanan darah.

\section{SIMPUL DAN SARAN}

\section{Simpulan}

Hasil tekanan darah pada ibu menopause sebelum di berikan jus buah naga merah (Hylocereus Polyrhizzus) hampir sebagian responden ibu menopause yang mengalami tekanan darah tinggi dengan kategori hipertensi ringansebanyak 8 responden mengalami tekanan darah sedang $(42,1 \%)$.

Hasil tekanan darah pada ibu menopause sesudah di berikan jus buah naga merah (Hylocereus Polyrhizzus) hampir seluruh ibu menopause mengalamipenurunan tekanan darah tinggi sebanyak 16 responden $(84,2 \%)$ mengalami penurunan tekanan darah.

Pemberian jus buah naga merah (Hylocereus Polyrhizzus) efektiv menurunkan tekanan darah tiunggi pada ibu menopause di Posyandu Banjaran Wilayah Kerja Puskesmas Wilayah Utara Kota Kediri dengan nilai $p$-value sebesar 0,002 atau $p$-value $<\alpha(0,000<0,005)$, artinya $\mathrm{H}_{\mathrm{o}}$ ditolak dan Hi diterima.

\section{Saran}

Bagi Institusi Penelitian, Diharapkan agar menjadikan hasil penelitian ini sebagai tambahan referensi dan wacana di lingkungan pendidikan serta sebagai bahan kajian lebih lanjut, khususnya untuk penelitian yang sejenisnya.

Tempat Penelitian, Diharapkan posyandu banjaran wilayah kerja puskesmas wulayah utara kota kedirisecara kontiyu melakukan skrining kesehatan, home care serta lebih aktif dalam 
meningkatkan keikutsertaan ibu menopausedalam melakukan kunjungan posyandu untuk mendapat informasi serta mendeteksi masalah-masalah yang dialami ibu khususnya pada tekanan darah tinggi.

Bagi Responden, Bagi ibu menopause agar mengkonsumsi jus buah naga merah untuk menurunkan tekanan darah tinggi dan mencegah terjadinya kenaikan tekanan darah dan masalah lainya.

Bagi Peneliti Selanjutnya, Diharapkan menjadi masukan bagi peneliti selanjutnya dalam melakukan penelitian yang lebih menarik lagi untuk mengurangi tekanan darah tinggi pada ibu menopause.

\section{KEPUSTAKAAN}

Arusadi.

(2013). Definisi, Etiologi dan Mekanisme Hipertensi. Bersumber dari http://blogkesmas.blogspot.com/2010/11/definisi-etiologi-dan mekanismes.html [Diakses Februari2018].

Depkes. (2013). Riset Kesehatan Dasar. Jakarta: KEMENKES RI.

Departemen Kesehatan RI. (2012). Pedoman Penemuan Dan Tata Laksana Penyakit Hipertensi. Jakarta: Direktorat Pengendalian Penyakit Tidak Menular Direktorat Jendral PP \& PL Depkes RI.

Departemen Kesehatan RI. (2012). Pharmaceuntical Care Untuk Penyakit Hipertensi. Jakarta: Depertemen Kesehatan RI.

Dinkes Jatim. (2013). Prevalensi hipertensi di Jawa Timur. Bersumber dari: http://dinkes.jatimprov.go.id/index.php?r=site/file list\&.

Feby. (2014). Pemberian Jus Buah Naga Merah (hylocereus polyrhizus).

Hasdianah, \& Sentot. (2014). Patologi dan patofisiologi penyakit. Yogyakarta: Nuha Medika.

Hariyanto, A., \& Sulistyowati, R. (2015). Buku ajar keperawatan medical bedah 1. Yogyakarta: Arruzz Media.

Kemenkes RI. (2012). Masalah Hipertensi Di Indonesia. Dari htpp://www.depkes.go.id /index.php.

Kowalski, R., E. (2013). Buku Ajaran Ilmu Penyakit Dalam Jilid I Edisi V. Jakarta: Selemba Medika.

Lidiyawati. (2014). Hipertensi (Pengenalan, pencegahan, pengobatan). Jakarta: BIP.

Ardiansyah, M. (2013). Medikal Bedah untuk Mahasiswa. Jakarta: DIVA Press.

Nursalam. (2008). Metode penelitian ilmu kebidanan. Pendekatan Praktis. Edisi 3. Jakarta: Salemba Medika.

Notoatmodjo. (2010). Metodologi Penelitian Kesehatan. Jakarta: Rineka Cipta.

Sheps. (2013). Mayo Clinic Hipertensi Mengatasi Tekanan Darah Tinggi. Jakarta: PT Intisari Mediatama.

Syahban, J. (2012). Mengenal Mencegah Mengatasi Silent Killer Hipertensi. Bandung: Pustaka Widyamara.

Rattner, S., Mhathes, M., \& Siegler, E. (2015). High blood pressure hypertension. American Heart Association.

Robinson dalam Grrafika. (2013). Stability of red dragon fruit peel (Hylocereus Polyrhizus), Food pathogenic Microorganisme. Skripsi. Surabaya: Universitas Pelita Harapan.

Thomas. (2013). Faktor Resiko Pola Konsumsi Natrium, Kalium, Serta Status Obesitas Terhadap Kejadian hipertensi di Puskesmas Lailangga, Jurnal Kesehatan. Program Studi Ilmu Gizi Universitas Hasanuddin. Makassar. 
Udjianti, J., W. (2015). Keperawatan kardiovaskular. Jakarta: Salemba Medika.

WHO. (2013). Q \& As on hypertension. Bersumber dari http://www.who.int [Diaksestanggal 20 februari 2018].

Wu Li Chen, et al. (2012). Efek Pemberian Jus Buah Naga Terhadap Penurunan Tekanan Darah (Hylocereus Polyrhizus).

Zamhir. (2012). Hipertensi, Respiratory Universitas Hasanuddin, Program Studi Ilmu Gizi Fakultas Kesehatan Masyarakat Universitas Hasanuddin. 